\title{
Plasma levels of soluble tumour necrosis factor receptors are increased in coal miners with pneumoconiosis
}

\author{
R.P.F. Schins, P.J.A. Borm
}

Plasma levels of soluble tumour necrosis factor receptors are increased in coal miners with pneumoconiosis. R.P.F. Schins. P.J.A. Borm. CERS Journals Ltd 1995.

ABSTRACT: Among other cytokines, tumour necrosis factor (TNF)- $\alpha$ is considered to play a key role in the development of mineral dust related fibrosis. Previously, we showed that $e x$-vivo release of TNF by peripheral blood monocytes is a marker for progression of coal workers' pneumoconiosis (CWP).

Since soluble TNF receptors (sTNF-Rs) are believed to play an important regulatory role in systemic effects of TNF, we measured plasma levels of STNF-R55 and sTNF-R75 in coal miners with $(n=28)$ or without $(n=76)$ CWP and in nonexposed controls $(n=29)$.

STNF-R75 levels were significantly increased in miners with CWP $(2.09 \pm 0.44$ $\left.\mathrm{ng} \cdot \mathrm{mL}^{-1}\right)$ versus the nonexposed controls $\left(1.86 \pm 0.23 \mathrm{ng} \cdot \mathrm{mL}^{-1}\right)$. Neither sTNF-R55 nor sTNF-R75 were related to exposure, stage of pneumoconiosis, smoking, or (spontaneous or ex-vivo induced) monocyte TNF-release. STNF-R55 was increased in subjects with medication (especially those using cardiovascular drugs); upon exclusion of these subjects, STNF-R55 was found also to be significantly increased in CWP.

In conclusion, bearing in mind a confounding effect of medication, soluble TNF receptors are elevated in plasma of retired miners with coal workers' pneumoconiosis. These observations further support the important role of TNF-mediated pathways in the pathogenesis of mineral dust related fibrosis.

Eur Respir J., 1995, 8, 1658-1663.

Dept of Health Risk Analysis and Toxicology, University of Limburg, Maastricht, The Netherlands

Correspondence: R.P.F. Schins

Dept of Health Risk Analysis and Toxicology University of Limburg

P.O. Box 616

NL-6200 MD Maastricht

The Netherlands

Keywords: Biological marker coal workers' pneumoconiosis soluble receptor

tumour necrosis factor- $\alpha$

Received: March 61995

Accepted after revision June 221995

This study was supported by grant No. $7263 / 03 / 092$ of the European Coal and Steel Community.
Occupational exposure to mineral dusts can lead to pulmonary fibrosis [1]. The pathogenesis of lung fibrosis involves highly complicated processes of intercellular communication by peptides released from and to various immune cells and lung target cells in a phenomenon appropriately referred to as "cytokine network" [2]. Previously, we and others have shown that silica, as well as coal mine dust, can stimulate the release of monocyte-/macrophagederived proinflammatory cytokines, such as tumour necrosis factor (TNF)- $\alpha$ [3-5], interleukin-1 $\beta$ (IL-1 $\beta$ ) $[4,6$, 7], interleukin-6 (IL-6) [5], and the macrophage inflammatory proteins la and 2 [8]. With regard to dust exposure in man, we found that monocyte TNF release upon ex-vivo stimulation with coal dust and silica (and endotoxin) was increased in (retired) miners with or without radiological evidence for simple coal workers pneumoconiosis (CWP) compared to subjects never exposed to mineral dust $[3,9]$. In line with our observations in monocytes of coal workers, higher TNF secretion was also observed in macrophages of patients with progressive massive fibrosis (PMF) compared to simple pneumoconiosis patients and control subjects [7]. More recently, elevated messenger ribonucleic acid (mRNA) levels of TNF (and IL-6) have been observed in lungs of pneumoconiosis patients [10]. Crucial evidence for the importance of TNF in silica-induced lung fibrosis was demonstrated by PIGUET et al. [11] who showed a downregulatory effect on fibrosis by TNF-antibody treatment.

Two distinct receptors of TNF, i.e. a $55 \mathrm{kDa}$ type (TNF-R55) and a $75 \mathrm{kDa}$ type (TNF-R75) have been identified, and both receptors are expressed on many different cell types and tissues [12-15]. Shedding of the extracellular parts of these TNF receptors from white blood cells and probably also other cell types leads to two soluble TNF receptor types, known as sTNF-R55 and sTNF-R75 [16, 17]. Since naturally occurring soluble TNF receptor levels are believed to play an important regulatory role in systemic effects of TNF $[16,18]$, plasma TNF receptor levels may represent a feedback mechanism to the proinflammatory systemic action of TNF, or an (in)direct reflection of TNF-related pathological mechanisms within the lung. In the present study, we determined soluble TNF receptors in plasma of coal miners with or without CWP and in controls never occupationally exposed to dust. The purpose of the study was to evaluate the relationship of soluble TNF receptors with cumulative (silica-) dust exposure and the biological effects of pneumoconiosis disease [19]. Secondly it was designed to evaluate the relationship between soluble TNF receptor levels and monocyte TNF release [9, 19] in nonexposed subjects and in coal workers either in the presence or absence of lung fibrosis. 


\section{Materials and methods}

As a part of a prospective cohort study among coal workers [20], soluble receptor levels were determined in the plasma of coal miners $(n=104)$ and non-dust-exposed controls $(n=29)$, after written informed consent. Prior to the blood sampling, a questionnaire, including informed consent was obtained from each participant. The study was conducted according to the Helsinki declaration of 1975. On the day of blood sampling, a chest radiograph was made of each miner. Confirmation of questionnaires and data from medical files and job history were obtained by personal interviews. Subjects were classified as smokers, nonsmokers, former smokers or lifetime nonsmokers; the amount smoked was expressed in pack years (packs $\cdot$ week $^{-1} \times$ years smoked). Smoking habits were verified using a personal interview and smoking data from previous cross-sectional studies [21, 22] to minimize reporting bias. The same was done for medical history. All subjects were divided into two categories, i.e. those who used any kind of medication and those who did not use medication for at least 3 days (or in the case of antibiotics for 1 week) prior to blood sampling.

Severity of pneumoconiosis was obtained by classification of chest radiographs by three occupational physicians [20], according to the standard protocol of the International Labour Organization (ILO) [23]. High resolution computed tomography (HRCT) was performed in a subgroup of 46 miners on a voluntary basis as described previously [24]. The cumulative dust exposure was determined from job-exposure matrices as described previously [25]. Blood (10 mL ethylenediamine tetra-acetic acid (EDTA)-tube) was sampled, transferred to the laboratory at $4^{\circ} \mathrm{C}$, and subsequently centrifuged. Plasma was stored at $-70^{\circ} \mathrm{C}$. Soluble receptor levels of R-55 and R75 were determined by sandwich enzyme-linked immunosorbent assay (ELISA) as described by LEEUWENBERG [26]. Briefly, immunoassay plates (Nunc Maxisorp, Roskilde, Denmark) were coated overnight at $4^{\circ} \mathrm{C}$ with monoclonal anti-TNF-R55 or anti-TNF-R75. Plates were saturated with $1 \%$ bovine serum albumin (BSA) in phosphate buffered saline (PBS) (w/v) for $1 \mathrm{~h}$ at room temperature. Test samples were added to the plates and incubated for $2 \mathrm{~h}$ at room temperature. Plates were washed and subsequently incubated with biotin-labelled rabbit antisTNF-R antiserum for $1 \mathrm{~h}$, followed by washing of the plates and addition of peroxidase labelled streptavidin. Peroxidase activity was determined spectrophotometrically after addition of 3,3',5,5'-tetramethylbenzidine substrate at $450 \mathrm{~nm}$ by ELISA-reader. Present ELISA methods show no interference between sTNF-R and TNF, as reported previously [26]. In the same subjects, monocyte TNF release was determined as reported previously $[3,9]$.

\section{Statistical analysis}

Study group characteristics were evaluated by the Student's t-test. Relations between the soluble TNF recep- tors R-55 and R-75 and age, pack-years, and dust exposure (i.e. miners only) were evaluated by linear regression. Multiple comparisons were evaluated by stepwise regression analysis. All statistical evaluations were made using Statgraphics version 6 (Manugistics Inc., Rockville, MA, USA).

\section{Results}

In the plasma of all individuals, levels of both soluble receptors were readily detectable (i.e. $>200 \mathrm{pg} \cdot \mathrm{mL}^{-1}$ ). Mean and standard deviations were $1.44 \pm 0.44 \mathrm{ng} \cdot \mathrm{mL}^{-1}$ (sTNF-R55) and $1.97 \pm 0.46 \mathrm{ng} \cdot \mathrm{mL}^{-1}(\mathrm{sTNF}-\mathrm{R} 75)$. Plasma levels of sTNF-R75, but not sTNF-R55, were significantly elevated in miners with pneumoconiosis compared to subjects never exposed to dust (table 1). Age in the nonexposed subjects was not different from miners with CWP, but was higher than in miners without radiological signs of pneumoconiosis (table 1). Cumulative exposure was higher in miners with CWP compared to the reference miners. Plasma levels of sTNF-R55 and sTNF-R75 were not different between current, former or lifetime nonsmokers in any of the subgroups, and not related to the severity of pneumoconiosis as defined by conventional chest radiograph or by HRCT (data not shown).

With the exception of age, no linear correlations were present between the soluble TNF receptors and other variables such as smoking, dust exposure and monocyte TNF release (table 2). A stepwise multiple regression analysis on both soluble TNF receptors using age, cumulative dust exposure (miners only), pack-years smoked, medication, spontaneous- and coal dust-stimulated monocyte TNF release as independent variables was performed in each study group. In the reference miners, both age $(\mathrm{t}=2.39 ; \mathrm{p}<0.025)$ and medication $(\mathrm{t}=-2.32 ; \mathrm{p}<0.025)$ gave a significant fit in the model to sTNF-R55, but in the nonexposed controls only medication $(\mathrm{t}=-3.12, \mathrm{p}<0.005)$ was significantly related to sTNF-R55. Subjects using medication had increased plasma levels of sTNF-R55 compared to subjects without medication (table 3). Among the reference miners (but not in other groups), age was significantly higher in those having medication (table 3 ), thus explaining the correlation between age and plasma sTNF-R55 levels in this subgroup. None of the variables was related to sTNF-R75 levels in any of the subgroups. Moreover, no relation was found between plasma levels of sTNF-R55 or sTNF-R75 and (spontaneous or ex-vivo induced) monocyte TNF release (table 2).

Because of the significant effects of medication on sTNFR55 levels, statistical analysis was repeated after exclusion of all subjects using medication. The difference in sTNF-R75 between CWP miners and nonexposed controls remained significant (fig. 1b), but now an increase of sTNF-R55 was also observed in miners with CWP $(\mathrm{p}<0.06$ vs reference miners). This confounding effect of medication on sTNF-R55 and the increased tendency in sTNF-R55 in pneumoconiosis is illustrated in figure 1a. Again, in this analysis no significant correlations were 
Table 1. - Study group characteristics and plasma levels of the soluble tumour necrosis factor (TNF) receptors, sTNFR55 and sTNF-R75, in miners with coal workers pneumoconiosis (CWP), reference miners and a non-dust exposed control group

\begin{tabular}{|c|c|c|c|c|}
\hline & & $\begin{array}{c}\text { Controls } \\
\text { Nonexposed } \\
(n=29)\end{array}$ & $\begin{array}{c}\text { Coal miners } \\
\text { Reference } \\
(\mathrm{n}=76)\end{array}$ & $\begin{array}{c}\text { Coal miners } \\
\text { with CWP } \\
(\mathrm{n}=28)\end{array}$ \\
\hline \multirow{2}{*}{\multicolumn{2}{|c|}{ Age yrs }} & $50 \pm 5^{*}$ & $48 \pm 5$ & $50 \pm 6$ \\
\hline & & $42-59$ & $37-60$ & $41-60$ \\
\hline \multirow{2}{*}{\multicolumn{2}{|c|}{ Smoking pack-yrs }} & $103 \pm 101$ & $111 \pm 107$ & $150 \pm 129$ \\
\hline & & $0-465$ & $0-520$ & $0-476$ \\
\hline Medication - no & $\mathrm{n}$ & 21 & 56 & 21 \\
\hline$-\operatorname{yes}^{\dagger}(\mathrm{I})$ & $\mathrm{n}$ & 0 & 5 & 2 \\
\hline (II) & $\mathrm{n}$ & 2 & 4 & 0 \\
\hline (III) & $\mathrm{n}$ & 1 & 3 & 1 \\
\hline (IV) & $\mathrm{n}$ & 0 & 4 & 2 \\
\hline (V) & $\mathrm{n}$ & 4 & 5 & 1 \\
\hline (VI) & $\mathrm{n}$ & 1 & 2 & 1 \\
\hline \multicolumn{2}{|c|}{ Cumulative dust exposure $\mathrm{g} \cdot \mathrm{h} \cdot \mathrm{m}^{-3}$} & - & $\begin{array}{c}91 \pm 56 \\
(10-280)\end{array}$ & $\begin{array}{l}131 \pm 50 * * \\
(23-203)\end{array}$ \\
\hline \multirow{2}{*}{\multicolumn{2}{|c|}{$\mathrm{sTNF}-\mathrm{R} 55 \mathrm{ng} \cdot \mathrm{mL}^{-1}$}} & $1.47 \pm 0.48$ & $1.39 \pm 0.43$ & $1.52 \pm 0.44$ \\
\hline & & $(0.78-2.55)$ & $(0.36-2.67)$ & $(0.96-3.08)$ \\
\hline \multirow{2}{*}{\multicolumn{2}{|c|}{$\mathrm{sTNF}-\mathrm{R} 75 \mathrm{ng} \cdot \mathrm{mL}^{-1}$}} & $1.86 \pm 0.23$ & $1.96 \pm 0.53$ & $2.09 \pm 0.44^{\#}$ \\
\hline & & $(1.47-2.51)$ & $(1.05-3.68)$ & (1.44-3.35) \\
\hline
\end{tabular}

Values are presented as mean $\pm \mathrm{SD}$ (range) evaluated by the Student's t-test. *: $\mathrm{p}<0.05$ and $* *: \mathrm{p}<0.01$, significantly different from reference miners; \#: $\mathrm{p}<0.01$, significantly different from non-dust exposed controls. CWP: miners with coal workers' pneumoconiosis (International Labour Office (ILO) chest radiograph $>0 / 0$ ). $\quad$ : subjects were classified according to six treatment categories: (I) inhalation drugs, i.e. $\beta$-agonists, corticosteroids and theophylline $(\mathrm{n}=7)$; (II) cardiovascular drugs, i.e. $\beta$-blockers and diuretics ( $\mathrm{n}=6)$; (III) immunosuppresssive and anti-inflammmatory drugs and allopurinol $(\mathrm{n}=5)$; (IV) antibiotics $(\mathrm{n}=6)$; (V) $\mathrm{H}_{2}$-agonists, laxantia, anti-psychotica and thyroid function drugs $(n=10)$; (VI) others $(n=4)$. In reference miners three subjects used two types of medication.

Table 2. - Correlation of plasma levels of the soluble tumour necrosis factor (TNF) receptors sTNF-R55 and sTNFR75 with age, smoking, dust exposure, and monocytes TNF release

\begin{tabular}{|c|c|c|c|c|}
\hline & $\begin{array}{l}\text { Soluble } \\
\text { receptor }\end{array}$ & $\begin{array}{c}\text { Controls } \\
\text { Nonexposed } \\
(n=29)\end{array}$ & $\begin{array}{l}\text { Reference coal } \\
\text { miners } \\
(n=76)\end{array}$ & $\begin{array}{l}\text { Coal miners } \\
\text { with CWP } \\
\quad(n=28)\end{array}$ \\
\hline \multirow[t]{2}{*}{ Age yrs } & sTNF-R55 & $0.02 \quad(0.92)$ & $0.34(0.003)$ & $0.20(0.30)$ \\
\hline & sTNF-R75 & $0.12 \quad(0.54)$ & $0.19(0.10)$ & $-0.18 \quad(0.37)$ \\
\hline \multirow[t]{2}{*}{ Smoking pack-yrs } & sTNF-R55 & $0.19 \quad(0.32)$ & $0.08(0.51)$ & $-0.09 \quad(0.64)$ \\
\hline & sTNF-R75 & $0.10 \quad(0.60)$ & $0.00(0.99)$ & $-0.04 \quad(0.83)$ \\
\hline \multirow[t]{2}{*}{ Underground working yrs } & sTNF-R55 & - & $0.19(0.11)$ & $-0.16 \quad(0.43)$ \\
\hline & sTNF-R75 & - & $0.16(0.18)$ & $-0.06 \quad(0.77)$ \\
\hline \multirow[t]{2}{*}{ Cumulative dust exposure $\mathrm{g} \cdot \mathrm{h} \cdot \mathrm{m}^{-3}$} & sTNF-R55 & - & $0.09(0.45)$ & $0.10 \quad(0.60)$ \\
\hline & sTNF-R75 & - & $0.04(0.70)$ & $0.06 \quad(0.75)$ \\
\hline \multicolumn{5}{|l|}{ TNF release $\mathrm{ng} \cdot \mathrm{mL} \cdot-1$} \\
\hline \multirow[t]{2}{*}{ Spontaneous } & sTNF-R55 & $-0.09 \quad(0.66)$ & $0.13(0.26)$ & $-0.06 \quad(0.76)$ \\
\hline & sTNF-R75 & $-0.05 \quad(0.79)$ & $0.11 \quad(0.35)$ & $-0.08 \quad(0.70)$ \\
\hline \multirow[t]{2}{*}{ LPS $3 \mathrm{ng} \cdot \mathrm{mL}^{-1}$} & sTNF-R55 & $0.18 \quad(0.35)$ & $0.17(0.14)$ & $-0.03 \quad(0.90)$ \\
\hline & sTNF-R75 & $\begin{array}{ll}-0.11 \quad(0.59)\end{array}$ & $0.15(0.19)$ & $-0.11 \quad(0.57)$ \\
\hline \multirow[t]{2}{*}{ LPS $\quad 1,000 \mathrm{ng} \cdot \mathrm{mL}^{-1}$} & sTNF-R55 & $0.04 \quad(0.84)$ & $0.06(0.60)$ & $-0.05 \quad(0.80)$ \\
\hline & sTNF-R75 & $\begin{array}{ll}-0.17 & (0.39)\end{array}$ & $0.09 \quad(0.42)$ & $-0.02 \quad(0.90)$ \\
\hline \multirow[t]{2}{*}{ Coal dust $5 \mathrm{mg} \cdot \mathrm{mL}^{-1}$} & sTNF-R55 & $0.33 \quad(0.08)$ & $0.06(0.63)$ & $0.18 \quad(0.36)$ \\
\hline & sTNF-R75 & $0.13 \quad(0.51)$ & $0.07(0.52)$ & $0.01 \quad(0.93)$ \\
\hline \multirow[t]{2}{*}{ Silica $0.5 \mathrm{mg} \cdot \mathrm{mL}^{-1}$} & sTNF-R55 & $0.35 \quad(0.06)$ & $0.12(0.29)$ & $0.26(0.18)$ \\
\hline & sTNF-R75 & $0.09 \quad(0.66)$ & $0.00(0.96)$ & $0.11(0.58)$ \\
\hline
\end{tabular}

All values are linear correlation coefficients, and p-values in parentheses. CWP: miners with coal workers pneumoconiosis (International Labour Office(ILO)) chest radiograph >0/0; LPS: lipopolysaccharide endotoxin.

present between the soluble receptors and smoking or exposure, nor was a correlation observed with age. The previously significant correlation with age in the reference miners $(n=76)$ was not present in the reference miners without medication $(n=55, p>0.25)$. Again, no relation between soluble receptors and monocyte TNF release was 
Table 3. - Effect of medication on plasma levels of soluble tumour necrosis factor (TNF) receptors, and its relation with age, smoking and cumulative dust exposure

\begin{tabular}{|c|c|c|c|c|c|c|}
\hline & \multicolumn{2}{|c|}{ Controls } & \multicolumn{4}{|c|}{ Coal miners } \\
\hline & \multicolumn{2}{|c|}{ Nonexposed } & \multicolumn{2}{|c|}{ Reference miners } & \multicolumn{2}{|c|}{ Miners with CWP } \\
\hline & $\begin{array}{c}\text { Medication } \\
(\mathrm{n}=8)\end{array}$ & $\begin{array}{l}\text { No medication } \\
(\mathrm{n}=21)\end{array}$ & $\begin{array}{l}\text { Medication } \\
\quad(\mathrm{n}=20)\end{array}$ & $\begin{array}{l}\text { No medication } \\
\quad(\mathrm{n}=56)\end{array}$ & $\begin{array}{l}\text { Medication } \\
\quad(\mathrm{n}=7)\end{array}$ & $\begin{array}{l}\text { No medication } \\
\quad(\mathrm{n}=21)\end{array}$ \\
\hline Age yrs & $50 \pm 6$ & $50 \pm 5$ & $50 \pm 5 *$ & $47 \pm 5$ & $49 \pm 6$ & $50 \pm 6$ \\
\hline Smoking pack-yrs & $139 \pm 90$ & $106 \pm 111$ & $99 \pm 87$ & $115 \pm 143$ & $178 \pm 109$ & $141 \pm 136$ \\
\hline Cumulative exposure $\mathrm{g} \cdot \mathrm{h} \cdot \mathrm{m}^{-3}$ & - & - & $101 \pm 67$ & $88 \pm 52$ & $132 \pm 43$ & $131 \pm 53$ \\
\hline $\mathrm{sTNF}-\mathrm{R} 55 \mathrm{ng} \cdot \mathrm{mL}^{-1}$ & $1.86 \pm 0.65^{* *}$ & $\quad 1.32 \pm 0.29$ & $1.63 \pm 0.50 * *$ & $1.30 \pm 0.38$ & $1.57 \pm 0.35$ & $1.50 \pm 0.47$ \\
\hline sTNF-R75 $\mathrm{ng} \cdot \mathrm{mL}^{-1}$ & $1.88 \pm 0.18$ & $1.85 \pm 0.25$ & $2.10 \pm 0.54$ & $1.91 \pm 0.51$ & $2.15 \pm 0.62$ & $2.07 \pm 0.38$ \\
\hline
\end{tabular}

Values are presented as mean \pm SD evaluated by the Student's t-test. $*: \mathrm{p}<0.05$ and $* *: \mathrm{p}<0.01$ significantly different from subject without medication in the same group. For abbreviations see legend to table 1.
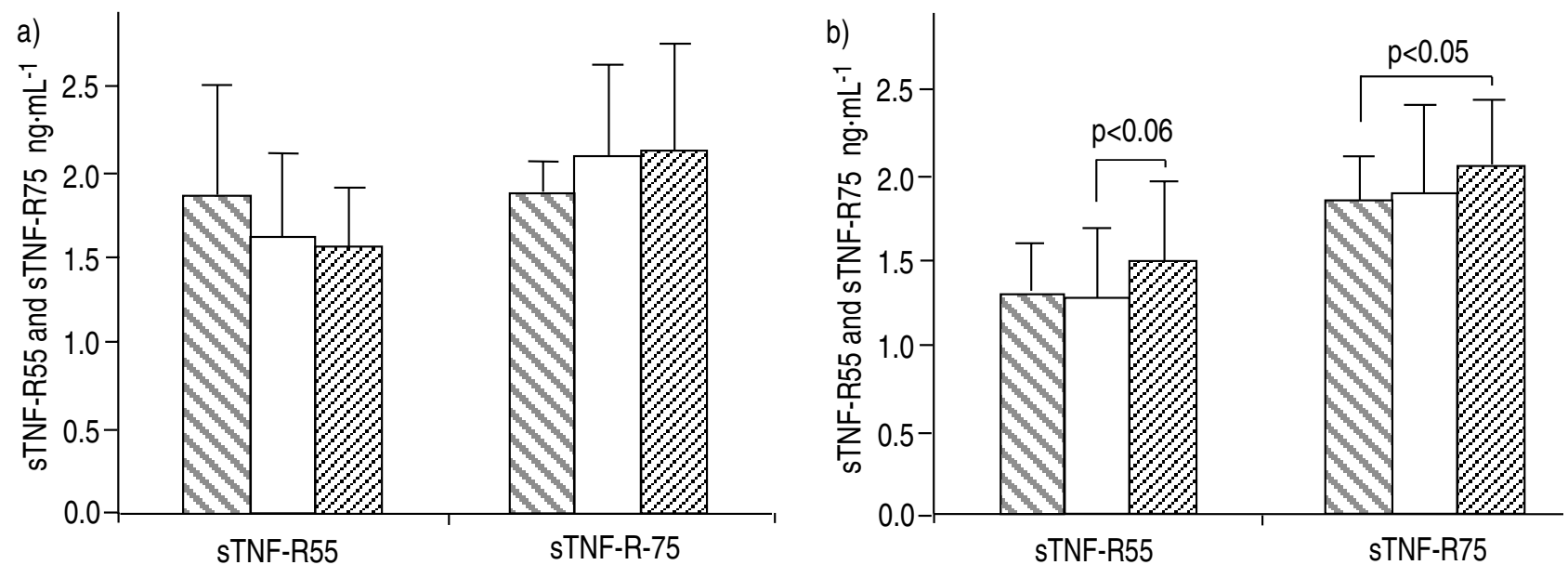

Fig. 1. - Effect of medication on plasma levels of the soluble tumour necrosis factor receptors (sTNF-R55 and sTNF-R75) in non-exposed controls ( $\square$ ), reference miners $(\square)$, and miners with coal workers pneumoconiosis (CWP) ( $\square$ ): a) Receptor levels of subjects with medication (controls $n=8$; reference miners $n=20$; miners with CWP $n=7$; total 35): b) All subjects without medication (controls $n=21$, reference miners $n=56$, miners with CWP $n=21$; total 98). Bars represent mean \pm sD, evaluated by the Student's t-test.

seen in subjects not using medication (data not shown).

\section{Discussion}

To the best of our knowledge, this study is the first to describe a significant increase in plasma soluble TNF receptors in (simple) coal workers pneumoconiosis. STNFR75 levels were significantly increased in miners with CWP compared to the nonexposed controls. Controls (nonexposed), as well as reference miners, who used medication at the time of blood sampling also had increased levels of sTNF-R55, but upon statistical exclusion of these subjects, sTNF-R55 was also increased in CWP. No effect of smoking was seen and a relation of sTNF-R55 with age could be attributed to the effect of medication.

In the present study, no relation was found between monocyte TNF release and plasma levels of both soluble TNF receptors. Several reasons can account for this lack of correlation. Firstly, it is unlikely that monocytes are the main source of sTNF-R in vivo. Secondly, monocyte TNF release was determined ex-vivo in standardized culture conditions, where cells were seeded at equal concentrations in culture dishes, while plasma sTNF-R levels might be related to individual variations in white blood cell concentrations. Unfortunately, no differential or total cell counts of the blood were available.
Since all miners in our study were retired, acute effects of coal dust exposure can be excluded. Moreover, plasma receptor levels were not related to cumulative dust exposure. In the miners with CWP $(n=28)$, a clear relation with disease severity, as determined by conventional chest radiograph or HRCT could not be established (data not shown). From these observations, one might conclude that levels of sTNF-R55 and sTNF-R75 could play a role in the pathogenesis of CWP.

Although many cytokines and growth factors are known to be involved in pulmonary fibrosis, the role of the "early" proinflammatory cytokine TNF- $\alpha$ as a central mediator in mineral dust related fibrosis is underscored by several in vitro and in vivo data [3-5, 7, 10, 27, 28]. The recent discovery of soluble cytokine antagonists and particularly the soluble TNF receptors R55 and R75 - have put things in a new perspective: soluble cytokine receptors could, on the one hand, act as powerful antagonists of various cytokine actions, but, on the other hand, increase cytokine related effects by a systemic carrier function of shortlived cytokines [17, 29]. PigueT and VESIN [30] demonstrated a downregulatory effect of TNF-antibodies [11], and more recently of sTNF-R55 in mineral dust related fibrosis. Doing so, they not only proved the crucial role of TNF in this disease, but they also elucidated a possible (therapeutic) role of soluble 
TNF receptors in mineral dust related fibrosis. Increased levels of soluble TNF receptors have been observed in several chronic and acute diseases [31-35]. In chronic lung disease sTNF-R55 and sTNF-R75 were found to be elevated in the bronchoalveolar lavage fluid of patients with idiopathic pulmonary fibrosis and sarcoidosis [36]. In line with our observations on monocyte TNF release in coal miners [3, 9, 19], sTNF-R55 and sTNF-R75, therefore, also may play a role in the pathogenesis of coal workers' pneumoconiosis.

Unlike sTNF-R55, plasma levels of sTNF-R75 in the present study were clearly elevated in the plasma of miners with simple coal workers pneumoconiosis. Moreover, sTNF-R75 levels were not affected by medication. This might be in line with recent observations that TNF induced receptor shedding from peripheral blood neutrophils is specific to TNF-R75 [37]. Similarly, the (slower) release of TNF receptors form mononuclear cells in response to lipopolysaccharide (LPS) is a process also predominantly observed for TNF-R75 compared to TNF-R55 [38].

From the above data one might consider the applicability of plasma determination of soluble TNF receptors with regard to monitoring, as previously suggested for high ex-vivo monocyte TNF release as a positive risk factor for disease progression of CWP [9, 19]. However, one should be aware of confounding factors on soluble TNF receptor measurements. Since the kidney is believed to be the main clearance route of soluble TNF receptors, any abnormality in renal function would result in altered plasma levels of both receptors [39]. SHAPIRO et al. [34] have also stressed the importance of appropriate blood processing for STNF-R determinations. In the present study, we observed an effect of medication on plasma levels of sTNF-R55. Due to a limited number of subjects using medication, we can only speculate on the action of specific types of medication, although higher plasma levels of sTNF-R55 were found in those subjects using cardiovascular drugs compared to subjects without medication $(\mathrm{p}<0.05 \mathrm{n}=6)$. Whether (in)direct action of the drugs, or, on the other hand, the (history of) cardiovascular pathogenesis in these medicated subjects alters plasma sTNF-R55 kinetics (e.g. transcription, internalization, shedding, renal clearance) remains to be elucidated. However, it should be realized that in this small subgroup other effects may also account for increased sTNF-R55 levels.

In conclusion, both sTNF-R55 and sTNF-R75 are increased in coal workers pneumoconiosis, although differences in receptor levels with exposed or nonexposed control groups may be confounded by the effect of medication used at the time of blood sampling. The increased levels of soluble TNF receptors further support the important role of TNF in pneumoconiosis in coal workers. Interactions between TNF release and the antagonistic actions of soluble TNF receptors could be important in the development or progression of CWP. If so, measurement of these receptors may be of additional value in routine screening of dust exposed individuals. Support for this should be derived from a prospective study among coal workers, allowing a con- comitant evaluation of TNF and its soluble receptors as risk markers.

Acknowledgements: The authors thank all coal miners and the Kempense Steenkoolmijnen NV for their willingness to co-operate in this study; M. van Sprundel, L. Lenaerts, and L. Mariën for reading the radiographs; B. Préat for the calculation of individual cumulative exposure; W.A. Buurman from the Department of Surgery, University of Limburg, The Netherlands, for useful advice and for providing antibodies and standards for sTNF-R55 and sTNF-R75 ELISA.

\section{References}

1. Crystal, RG, Ferrans VJ, Basset F. Biologic basis of pulmonary fibrosis. In: Crystal RG, West JB, Barnes PJ, Cherniack NS, Weibel ER, eds. The lung: Scientific Foundations. New York, Raven Press, 1991; pp. 20312046.

2. Elias JA, Freundlich B, Kern JA, Rosenbloom J. Cytokine networks in the regulation of inflammation and fibrosis in the lung. Chest 1990; 97: 1439-1445.

3. Borm PJA, Palmen N, Engelen JJM, Buurman WA. Spontaneous and stimulated release of tumor necrosis factor-alpha (TNF) from blood monocytes of miners with coal workers' pneumoconiosis. Am Rev Respir Dis 1988; 138: 1589-1594.

4. Driscoll KE, Lindenschmidt RC, Maurer JK, Higgins JM, Ridder G. Pulmonary response to silica or titanium dioxide: inflammatory cells, alveolar macrophage-derived cytokines, and histopathology. Am J Respir Cell Mol Biol 1990; 2: 381-390.

5. Gosset P, Lasalle P, Vanhée D, et al. Production of tumor necrosis factor- $\alpha$ and interleukin- 6 by human alveolar macrophages exposed in vitro to coalmine dust. Am J Respir Cell Mol Biol 1991; 5: 431-436.

6. Schmidt JA, Oliver CN, Lepe-Zuniga JL, Green I, Grey I. Silica stimulated monocytes release fibroblast proliferation factors identical to interleukin-1: potential role for interleukin-1 in the pathogenesis of silicosis. J Clin Invest 1984; 73: 1462-1472.

7. Lasalle P, Gosset P, Aerts C, et al. Abnormal secretion of interleukin-1 and tumor necrosis factor- $\alpha$ by alveolar macrophages in coal workers' pneumoconiosis: comparison between simple pneumoconiosis and progressive massive fibrosis. Exp Lung Res 1990; 16: 73-80.

8. Driscoll KE, Hassenbein DG, Carter J, et al. Macrophage inflammatory proteins 1 and 2: expression by rat alveolar macrophages, fibroblasts, and epithelial cells in rat lung after mineral dust exposure. Am J Respir Cell Mol Biol 1993; 8: 311-318.

9. Schins RPF, Borm PJA. Epidemiological evaluation of release of monocyte TNF- $\alpha$ as an exposure and effect marker in pneumoconiosis: a five year follow-up study. Occup Environ Med, 1995; 52: 441-450.

10. Vanhée D, Gosset P, Marquette CH, et al. Secretion and mRNA expression of TNF- $\alpha$ and IL-6 in the lung of pneumoconiotic patients. Am J Respir Dis 1993; 147: A906.

11. Piguet PF, Collart MA, Grau GE, Sappino AP, Vassali P. Requirement of tumor necrosis factor for development of silica-induced pulmonary fibrosis. Nature 1990; 344: 245-247.

12. Brockhaus M, Schoenfeld H-J, Schlaeger E-J, Hunziker W, Lesslauer W, Loetscher H. Identification of two types of tumor necrosis factor receptors on human cell lines 
by monoclonal antibodies. Proc Natl Acad Sci USA 1990; 87: 3127-3131.

13. Loetscher H, Pan YE, Lahm H-W, et al. Molecular cloning and expression of the human $55 \mathrm{kd}$ tumor necrosis factor receptor. Cell 1990; 61: 351-359.

14. Schall TJ, Lewis M, Koller KJ, et al. Molecular cloning and expression of a receptor for tumor necrosis factor. Cell 1990; 61: 361-370.

15. Smith GA, Davis T, Anderson D, et al. A receptor for tumor necrosis factor defines an unusual family of cellular and viral proteins. Science 1990; 248: 1019-1023.

16. Jäätelä M. Biology of disease: biologic activities and mechanisms of action of tumor necrosis factor- $\alpha /$ cachectin. Lab Invest 1991; 64: 724-742.

17. Beutler B, Grau GE. Tumor necrosis factor in the pathogenesis of infectious diseases. Crit Care Med 1993; 21: S423-S435.

18. Sheperd VL. Cytokine receptors of the lung. Am J Respir Cell Mol Biol 1991; 5: 403-410.

19. Borm PJA. Biological markers and occupational lung disease. Exp Lung Res 1994; 20: 457-470.

20. Schins RPF, Borm PJA, Lenaerts L. Tumor necrosis factor (TNF) and progression of coal workers' pneumoconiosis in retired coal miners. In: Mohr U, Dungworth DL, Mauderly JL, Oberdörster G, eds. Toxic and Carcinogenic Effects of Solid Particles in the Respiratory Tract. Washington, ILSI Press, 1994; pp. 423-427.

21. Borm PJA, Meijers JMM, Swaen GMH. Molecular epidemiology of coal workers' pneumoconiosis: application to risk assessment of oxidant and monokine generation by mineral dusts. Exp Lung Res 1990; 16: 57-71.

22. Janssen YMW, Engelen JJM, Giancola MS, Low RB, Vacek P, Borm PJA. Serum type III procollagen Nterminal peptide in coal miners. Exp Lung Res 1992; 18: $1-8$

23. International Labour Organisation. Guidelines for the use of ILO international classification of radiographs of pneumoconioses, 1980. Geneva International Labour Office (Occupational Safety and Health series No. 22, revised).

24. Lamers RJS, Schins RPF, Wouters EFM, van Engelshoven JMA. Computed tomography of the lungs in coal workers with a normal chest radiograph. Exp Lung Res 1994; 21: 411-419.

25. Jorna THJM, Schins RPF, Lenaerts L, Derhaag TJJM, Wouters EFM, Borm PJA. Airflow obstruction and monocyte TNF release in coal workers. Exp Lung Res 1994; 20: 421-431.

26. Leeuwenberg JFM, Jeunhomme TMAA, Buurman WA. Slow release of soluble TNF receptors by monocytes in vitro. J lmmunol 1994; 152: 4036-4043.
27. Mohr C, Gemsa D, Graebner C, et al. Systemic macrophage stimulation in rats with silicosis: enhanced release of tumor necrosis factor- $\alpha$ from alveolar and peritoneal macrophages. Am J Respir Cell Mol Biol 1991; 5: 395-402.

28. Perkins RC, Scheule RK, Hamilton R, Freidman G, Holian A. Human alveolar macrophage cytokine release in response to in vitro and in vivo asbestos exposure. Exp Lung Res 1993; 19: 55-65.

29. Ulich TR, Yin S, Remick DG, Russell D, Eisenberg SP, Kohno T. Intratracheal administration of endotoxin and cytokines. IV. The soluble tumor necrosis factor receptor type I inhibits acute inflammation. Am J Pathol 1993; 142: $1335-1338$.

30. Piguet PF, Vesin C. Treatment by human recombinant soluble TNF receptor of pulmonary fibrosis induced by bleomycin or silica in mice. Eur Respir $J$ 1994; 7: 515-518.

31. Aderka D, Engelmann H, Hornik V, et al. Increased levels of soluble receptors for tumor necrosis factor in cancer patients. Cancer Res 1991; 51: 5602-5607.

32. Naylor MS, Stamp GWH, Foulkes WD, Eccles D, Balkwill FR. Tumor necrosis factor and its receptors in human ovarian cancer: potential role in disease progression. $J$ Clin Invest 1993; 91: 2194-2206.

33. Latini R, Bianchi M, Correale E, et al. Cytokines in acute myocardial infarction: Selective increase in circulating tumor necrosis factor, its soluble receptor, and interleukin-1 receptor antagonist. J Cardiovasc Pharmacol 1994; 23: 1-6.

34. Shapiro L, Clark BD, Orencole F, Poutsiaka DD, Granowitz EV, Dinarello CA. Detection of tumor necrosis factor soluble receptor p55 in blood samples from healthy and endotoxemic humans. J Infect Dis 1993; 167: 13441350.

35. Tilg H, Vogel W, Wiedermann CJ, et al. Circulating interleukin-1 and tumor necrosis factor antagonisis in liver disease. Hepatol 1993; 18: 1132-1138.

36. Walker C, Bauer W, et al. Activated T-cells and cytokines in bronchoalveolar lavage from patients with various lung diseases associated with eosinophilia. Am J Respir Crit Care Med 1994; 150: 1038-1048.

37. Porteu F, Hieblot C. Tumor necrosis factor induces a selective shedding of its p75 receptor from human neutrophils. J Biol Chem 1994; 269: 2834-2840.

38. Leeuwenberg JFM, Dentener MA, Buurman WA. Lipopolysaccharide (LPS)-mediated receptor release and TNF receptor expression by monocytes: Role of CD 14, LPS binding protein, and bactericidal/permeability-increasing protein. J Immunol 1994; 152: 5070-5076.

39. Bemelmans MHA, Gouma DJ, Buurman WA. Influence of nephrectomy on tumor necrosis factor clearance in a murine model. J Immunol 1993; 150: 2007-2017. 